\title{
Potato genotypes reaction to early blight and late blight in organic cultivation
}

\author{
Fábio José Busnello ${ }^{1}$ Mari Inês Carissimi Boff ${ }^{1}$ (iD) Lenita Agostinetto $^{2 *}$ (D \\ Zilmar da Silva Souza $^{3}$ Pedro Boff ${ }^{4}$ iD
}

${ }^{1}$ Departamento de Agronomia, Centro de Ciências Agroveterinárias (CAV), Universidade do Estado de Santa Catarina (UDESC), Lages, SC, Brasil.

${ }^{2}$ Programa de Pós-graduação em Ambiente e Saúde, Universidade do Planalto Catarinense (UNIPLAC), 88509900, Lages, SC, Brasil. E-mail: leagostinetto@yahoo.com.br. "Corresponding author.

${ }^{3}$ Empresa de Pesquisa Agropecuária e Extensão Rural de Santa Catarina (EPAGRI), Estação Experimental de São Joaquim, São Joaquim, SC, Brasil. ${ }^{4}$ Empresa de Pesquisa Agropecuária e Extensão Rural de Santa Catarina (EPAGRI), Estação Experimental de Lages, Laboratório de Homeopatia e Saúde Vegetal, Lages, SC, Brasil.

\begin{abstract}
Disease management in conventional potato crops requires the use of larger amounts of phytosanitary products and increased toxicity with regard to organic cultivation which may pose a risk to human health and have a negative impact on the environment as well. The present study aimed to evaluate the yield and the reaction of potato genotypes to both late blight and to early blight under an organic system of cultivation. Eperiments were conducted in the field in the municipalities of Lages, SC and Quilombo, SC, south Brazil, during the crops of 2012/2013 and 2013/2014. The experimental design consisted of a randomized complete block design with 4 replications; The following eight local clones from the Santa Catarina mountain range (serra) were evaluated: SJ01273-1; SJ01251-1; SJ01213-1; SMSJ07344-54; SJ04510-1; SJ05621-11; SJ02411-5; and SJ04521-3; and 8 commercial cultivars were assessed as follows: Agate, Asterix, and Monalisa of Dutch origin; Panda of German origin; and BRS Ana, BRS Eliza, Cota, and Catucha of Brazilian origin. Incidence and severity of late blight and early bright and the weight and number of tubers produced were evaluated. Potato genotypes showed variability in terms of tuber production and disease resistance. The regional clone 15 and cultivars BRS Ana and Cota presented resistance to early blight and to late blight in both cultivated sites. Genotype 35 and cvs. Asterix and BRS Ana were the ones that had the largest productions. Genotype 35 was the most productive one among all genotypes/clones evaluated $\left(16,926.81 \mathrm{~kg} \mathrm{ha}^{-1}\right)$. There was variability between different local potato genotypes in terms of productivity potential and resistance to diseases under the organic system of cultivation. These findings showed that there is a source of resistance to genetic improvement programs.

Key words: cultivar, rusticity, Solanum tuberosum.
\end{abstract}

Reação de genótipos de batata à pinta preta e requeima em cultivo orgânico

RESUMO: O manejo de doenças nos cultivos convencionais de batata requer emprego de maior quantidade de produtos fitossanitários e de maior toxicidade em relação ao cultivo orgânico, que pode acarretar riscos a saúde humana e impacto ambiental. Este trabalho teve como objetivo avaliar o rendimento e a reação de genótipos de batata à requeima e à pinta preta sob sistema orgânico de cultivo. Os experimentos foram conduzidos a campo nas safras 2012/2013 e 2013/2014 em Lages/SC e em Quilombo/SC. O delineamento experimental foi de blocos ao acaso com quatro repetições. Avaliou-se oito clones locais oriundas da serra catarinense: SJ01273-1; SJ01251-1; SJ01213-1; SMSJ0734454; SJ04510-1; SJ05621-11; SJ02411-5; SJ04521-3 e oito cultivares comerciais: Ágata, Asterix e Monalisa de origem holandesa; Panda de origem alemã e BRS Ana, BRS Eliza, Cota e Catucha de origem brasileira. Foram realizadas avaliações de incidência e severidade da requeima e pinta preta e do peso e número de tubérculos produzidos. Os genótipos de batata apresentaram variabilidade na produção de tubérculos e de resistência a doenças. O clone regional 15 e as cultivares BRS Ana e Cota apresentaram resistência à pinta preta e a requeima, em ambos os locais cultivados. O genótipo 35 e as cvs. Asterix e BRS Ana apresentaram as maiores produções. O genótipo 35 foi o mais produtivo $\left(16.926,81 \mathrm{~kg} \mathrm{ha}^{-1}\right)$. Genótipos locais de batata apresentam variabilidade quanto ao potencial produtivo e resistência a doenças sob o sistema orgânico de cultivo, evidenciando fonte de resistência a programas de melhoramento genético.

Palavras-chave: cultivar, rusticidade, Solanum tuberosum.

\section{INTRODUCTION}

Potato (Solanum tuberosum) cultivated with commercial varieties in Brazil has been shown to be vulnerable to a number of diseases and pests (GOMES et al., 2008). Late blight [Phytophthora infestans (Mont.) de Bary is a disease that affects the aerial part of the plant causing symptoms such as dark and irregular spots (specks, dots) with a drenching appearance (soaked aspect). In addition, there may be growth of the reproductive structures of the pathogen in the abaxial part of the leaves. In those cases in which the disease is severe, the oomycete may also affect the tubers causing tough and dark rot of these 
structures. Thus, late blight may cause destruction of the plant in just a few days which requires continuous monitoring of the crop (STEVENSON et al., 2013). In Brazil, this pathogen is spread from sporangia that are carried by rain splash and wind and survive from season to season through potato or tomato plants that persist in the field since the pathogen does not have a saprophytic stage in the soil (ZAMBOLIM \& DUARTE, 2012). Since this is a pathogen with rapid multiplication and dissemination, adequate preventive measures should be implemented in order to manage this disease successfully. Therefore, genetic control is considered an important alternative for integrated disease management (ZAMBOLIM \& DUARTE, 2012).

In addition, early blight is another important disease that can cause up to $30 \%$ of damage to potato production (STEVENSON et al., 2013). However, in Brazil early blight has been recently associated with the occurrence of distinct populations of Alternaria spp. affecting potatoes (LOURENÇO Jr et al., 2009). According to RODRIGUES et al. (2010), the causal agent of the disease and most prevalent species in the country is Alternaria grandis Simmons and not $A$. solani. However, symptoms caused by $A$. grandis in potatoes are very similar to those caused by $A$. solani in Brazil and in other countries as well (DUARTE et al., 2014). The disease is characterized by small dark specks (spots, dots) that mainly affects the lower and older leaves of the plant and occurs in conditions of high temperature (above $25^{\circ} \mathrm{C}$ ) and relative humidity (STEVENSON et al., 2013). The spread occurs through conidia of the fungus that are transported through splashing rain drops and by wind and can survive on cultural leftovers, infected tubers that persist in the field or other host plants. In addition, it is important to note that seed potato can be an important source of the initial inoculum of the disease and may disseminate it over long distances (ZAMBOLIM \& DUARTE, 2012). Thus, cultivars susceptible to early blight present a risk of introducing the disease into the field.

Thus, the correct identification, selection and use of genotypes with a certain degree of resistance to both patho-systems is fundamental especially in a organic cultivation system in which some management techniques are limited. Preventive management of diseases, especially of late blight, is essential to avoid production damage and guarantee productivity. In addition, genetic control is the most economical control measure for disease management especially for low income farmers (GRUNWALD et al., 2002).
Greater economic losses in commercial potato crops in southern Brazil are caused by early blight due to its highly destructive potential (FNPPPT, 2000; RAUBER, 2007; ZAMBOLIM \& DUARTE, 2012). In contrast, traditional potato subsistence crops have shown that potato plants have high genetic diversity even if their multiplication is almost exclusively clonal (CARPUTO et al., 2002). The expression of resistance when controlled by several genes is more likely to last and has greater plasticity in different environments and increased rusticity to the genotypes which guarantees resistance or tolerance to the pathogens that cause major diseases of potatoes (BRUNE et al., 1999; SIMON et al., 2009). Genotypes from successive regional crops have their genetic load selected for local edaphoclimatic adaptability. When grown in production systems with less input intervention, their resistance mechanisms are rapidly activated by an initial pathogen infection (ROBINSON, 2006). Therefore, potato cultivation with regional clones can be highly promising for organic production since it favors the expression of resistance and/or tolerance of plants to diseases and pests (ROSSI et al., 2011; SILVA et al., 2014; PASSOS et al., 2017).

In the region of the Planalto Sul Catarinense (plateau from the southern area of the State of Santa Catarina) in south Brazil, producers of family agriculture (family farming) are involved in the production of seed potatoes with the occasional use of local labor. The areas of cultivation are small due to the rugged geography. Such rough landscape offers the spatial discontinuity condition which helps to maintain genetic purity of cultivars and identity of local clones (RIBEIRO \& LEPRE, 2010). In such scenario, the present study aimed to evaluate the yield and the reaction of potato genotypes to both late blight and early blight under an organic system of culture.

\section{MATERIALS AND METHODS}

The research was conducted in the field between years 2012 and 2014 in two different environments: Environment 1 corresponds to the experimental area of the Agricultural Research and Rural Extension Company of Santa Catarina, EPAGRI, Lages, SC, south Brazil, located at latitude $27^{\circ} 48^{\prime}$, longitude $50^{\circ} 19^{\prime}$ and altitude of $931 \mathrm{~m}$. The climate is humid temperate and the average air temperature in the hottest month of the year is lower than $22^{\circ} \mathrm{C}$ and in the winter months ranges between $6^{\circ} \mathrm{C}$ and $8^{\circ} \mathrm{C}$. The predominant soil is classified as Humic Cambisol (Embrapa, 2013). In this environment the experiment 
was carried out during the cycles of years 2012/2013 and 2013/2014; Environment 2 refers to a rural property of a family farmer (Agricultor-Quilombo) which is located in the municipality of Quilombo, SC, south Brazil, at latitude $26^{\circ} 43^{\prime}$ south, longitude $52^{\circ} 43^{\prime}$, and altitude of 600 meters. The climate of the area is warm temperate with an average annual temperature of $24^{\circ} \mathrm{C}$. The soil is predominantly Dystrophic Latosol with gently undulated and well-drained relief (EMBRAPA, 2013). In this environment, the research study was conducted only during the cycle of years 2013/2014.

During the winter, green fertilization with black oats (Avena strigosa) was performed in both environments and was tumbled with a kniferoller without being dried in the milky-grain stage. After 15 days, they were made with floaters. The weeding was manual and heaped according to the need of cultivation.

The basal fertilization in environment 1 was $10 \mathrm{~m}^{3} \mathrm{ha}^{-1}$ of sheep manure and $300 \mathrm{~kg} \mathrm{ha}^{-1}$ of Arad rock phosphate $(9 \%$ soluble phosphorus in neutral ammonia citrate CNA) according to analysis of the most limiting factors of the soil. In Environment 2, the basic fertilization was carried out through chemical soil analysis with the addition of $10 \mathrm{~m}^{3} \mathrm{ha}^{-1}$ of organic manure Granu plant ${ }^{\circledR}$ with total nitrogen composition $1.0 \%$, organic carbon $20 \%$, humidity $25 \%$, pH 7.5 , CTC $340 \mathrm{cmolc}$, and $\mathrm{CTC}^{-\mathrm{c}} 17.00 \mathrm{cmolc}$ per volume.

Planting in Environment 1 occurred on Oct. 22, 2012 and Nov. 12, 2013 in the cycles of years 2012/2013 and 2013/2014, respectively. In Environment 2, the planting occurred on Dec. 9, 2013 in the cycle of years 2013/2014. The experiments were conducted in a randomized complete block design (DBC) with 4 replications. The experimental units consisted of 10 tubers spaced $0.30 \mathrm{~m}$ between plants and $0.80 \mathrm{~m}$ between rows, and the spacing between plots was $0.5 \mathrm{~m}$ without the cultivation of any other species, 8 genotypes (clones) from Santa Catarina and 8 commercial cultivars were cultivated and evaluated.

The local potato genotypes were obtained from the plant genetic improvement program of the Experimental Station of São Joaquim - EPAGRI and identified by the order number in the deposit to the germplasm bank of the respective station which were the following: 15 - Atlantic x Catucha - SJ01273-1; 35 Catucha x FL1625 - SJ01251-1; 95 - Atlantic x Tollocan - SJ01213-1; 144 - Panda $\mathrm{x}$ Atlantic - SMSJ07344-54; 162 - EESJ01733 x FL1625 - SJ04510-1; 172 - 3CRI1149 x Russet Burbank - SJ05621-11; 322 - Elvira x Monalisa -
SJ02411-5; and 334 - Monalisa x Cupid - SJ04521-3. The commercial cultivars were the following: Agate, Asterix, and Monalisa, of Dutch origin; BRS Ana, BRS Eliza, Cota and Catucha of Brazilian origin; and Panda of German origin.

The quantification of the incidence and severity of late blight and early blight occurred every 15 days starting at 20 days after planting in the emergence stage of the plants and first expanded leaves, and was extended until the end of flowering totaling 5 assessments. The severity of the diseases was estimated using a diagrammatic scale proposed by JAMES (1971) with reference values of $1 \%$, $10 \%, 25 \%$, and $50 \%$ of injured leaf area. The leaf incidence was estimated by the proportion of diseased leaves of each plant. For the evaluations, 6 plants of each plot were used.

The incidence and severity of the disease were expressed by leaf area below the incidence progress curve (AACPI) or disease severity (AACPS). The area was estimated for each index using the trapezoidal integralization method (BERGER, 1988; CAMPBELL \& MADDEN 1990). For the calculation of AACPI and AACPS, the following formula was used: $\sum_{1}^{n-1}\left(\frac{y 1+y 1+1}{2}\right)(t 1+1-t 1)$ in which: $\mathrm{n}=$ number of evaluations; $y=$ intensity, incidence or severity of disease; $\mathrm{t}=$ time when the intensity of the disease was evaluated; $(y i+y i+1)=$ mean height of the rectangle between points yi and $y i+1$ and $t i+1=$ difference of the base of the rectangle between points $t i+1$ and ti expressed by the proportion of disease versus time.

For the evaluation of yield, tubers of 10 plants of each plot at harvest time were counted and weighed. Number of tubers per plant was obtained by counting the tubers per plot corrected for the number of plants of each plot.

Data analysis was performed using linear models and ANOVA. The comparisons between the mean values of the treatments were done using of a Scott Knott 5\% test. The AACPI/S variable of Phytophthora infestans and Alternaria solani were calculated on the extent of all evaluations and compared between different sites and treatments.

\section{RESULTS AND DISCUSSION}

Scott-Knott group analysis $(\mathrm{P}<0.05)$ allowed us to separate 2 groups of local genotypes/ varieties with regard to their susceptibility to early blight considering AACPI/S in Environment 2/ Quilombo, cycle of years 2013/2014, and AACPS in Environment 1 / Lages, cycle from years 2012/2013 (Table 1). It should be noted that there was no 
difference between genotypes considering disease incidence in Environment 1 for both crop cycles years 2012/2013 or 2013/2014 - or for disease severity in Environment 1, cycle from years 2013/2014 (Table 1). Although, there was a statistical difference between the genotypes in environment 2, the AACPI and AACPS averages were very close to one another; and therefore, not very significant. However, it should be pointed out the fact that genotype 95 presented the highest mean disease incidence and disease severity in this environment; although, it did not differ statistically from other genotypes. In addition, clones 15, 162, and 322 as well as cultivars BRS Ana, BRS Eliza, and BRS Cota presented the lowest mean AACPI and AACPS simultaneously and differed statistically from the other genotypes (Table 1).

The CNPH clone CIP 015 was one of the most susceptible to early blight in field conditions presenting severity values ranging between $42 \%$ and $70 \%$ of the area in the symptoms of the disease were observed (OKITA et al, 2014). Similarly, cultivar BRS Ana is considered to be moderately susceptible to early blight (PEREIRA et al., 2010) and Cultivar Cota is also susceptible to this fungal disease (PERUCH \& SILVA, 2009). However, in this study, both showed low values of AACPI and AACPS for early blight. The effect of the planting date and variations in environmental conditions may influence the expression of plant genetics. According to PEREIRA et al. (2010), the BRS Ana cultivar showed differences in terms of productive potential and resistance to diseases when cultivated in different environments and at different times such as autumn and spring seasons.

Early blight may become destructive under conditions of high temperature $\left(25-30^{\circ} \mathrm{C}\right)$ and relative air humidity close to $90 \%$ (STEVENSON et al., 2013). Thus, maintenance of resistance when a plant is subjected to different temperature conditions, geographic locations, and variations in disease intensity requires regional studies to ascertain its response to a particular environment (SILVA et al., 2014).

Although, there were statistical differences between the potato genotypes in Environment 2, we were unable to state that the potato clones or

Table 1 - Intensity of the early blight (Alternaria solani) expressed by the area below the incidence progression curve (AACPI) and severity (AACPS) in potato genotypes grown under organic system of cultivation in two cycles, years 2012/2013 and years 2013/2014, Santa Catarina, Brazil.

\begin{tabular}{|c|c|c|c|c|c|c|}
\hline \multirow[t]{3}{*}{ Genotypes locals Cultivars } & \multicolumn{4}{|c|}{ 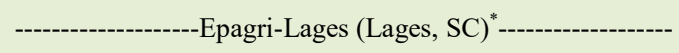 } & \multirow{2}{*}{\multicolumn{2}{|c|}{ Agricultor-Quilombo (Quilombo, SC) }} \\
\hline & \multicolumn{2}{|c|}{----------2012/2013--------- } & \multicolumn{2}{|c|}{----------2013/2014---------- } & & \\
\hline & AACPI & AACPS & AACPI & AACPS & AACPI & AACPS \\
\hline 15 & $75.00^{\text {ns }}$ & $12.30 \mathrm{~b}$ & $38.75^{\text {ns }}$ & $8.04^{\mathrm{ns}}$ & $48.50 \mathrm{~b}$ & $8.87 \mathrm{~b}$ \\
\hline 35 & 61.38 & $11.21 \mathrm{~b}$ & 26.25 & 9.69 & $61.13 \mathrm{a}$ & $10.71 \mathrm{~b}$ \\
\hline 95 & 101.8 & $15.27 \mathrm{a}$ & 25.50 & 8.04 & $81.88 \mathrm{a}$ & $22.82 \mathrm{a}$ \\
\hline 144 & 85.75 & $14.19 \mathrm{a}$ & 28.75 & 7.35 & $45.38 b$ & $18.21 \mathrm{a}$ \\
\hline 162 & 62.25 & $11.01 \mathrm{~b}$ & 46.50 & 7.35 & $68.25 \mathrm{a}$ & $8.97 \mathrm{~b}$ \\
\hline 172 & 99.75 & $13.77 \mathrm{a}$ & 22.88 & 7.35 & $62.25 \mathrm{a}$ & $9.64 b$ \\
\hline 322 & 155.0 & $14.25 \mathrm{a}$ & 31.75 & 7.69 & $47.63 b$ & $9.51 b$ \\
\hline 334 & 82.63 & $12.98 \mathrm{~b}$ & 50.00 & 8.74 & $60.13 a$ & $9.77 \mathrm{~b}$ \\
\hline ÁGATA & 106.3 & $12.55 \mathrm{~b}$ & 34.50 & 8.03 & $66.25 \mathrm{a}$ & $10.33 b$ \\
\hline ASTERIX & 96.13 & $14.53 a$ & 43.50 & 7.35 & $58.88 \mathrm{a}$ & $9.09 \mathrm{~b}$ \\
\hline BRS ANA & 60.88 & $10.80 \mathrm{~b}$ & 31.00 & 7.35 & $49.50 \mathrm{~b}$ & $10.33 b$ \\
\hline BRS ELIZA & 91.63 & $14.61 \mathrm{a}$ & 30.00 & 7.69 & $54.63 b$ & $9.23 b$ \\
\hline CATUCHA & 72.63 & $12.16 \mathrm{~b}$ & 37.13 & 7.35 & $60.50 \mathrm{a}$ & $9.79 \mathrm{~b}$ \\
\hline COTA & 60.50 & $10.80 \mathrm{~b}$ & 40.25 & 7.35 & $51.63 b$ & $8.96 \mathrm{~b}$ \\
\hline MONALISA & 79.50 & $12.30 \mathrm{~b}$ & 58.13 & 7.35 & $62.00 \mathrm{a}$ & $9.56 \mathrm{~b}$ \\
\hline PANDA & 130.5 & $15.86 \mathrm{a}$ & 43.50 & 7.35 & $59.88 \mathrm{a}$ & $10.59 b$ \\
\hline CV (\%) & 9.25 & 6.87 & 8.47 & 10.40 & 18.62 & 8.67 \\
\hline
\end{tabular}

*Averages followed by the same letter in the column do not differ from one another by the Scott-Knott test $(\mathrm{P} \leq 0.05)$. ns $=$ not $\mathrm{significant}$ by ANOVA F test $(\mathrm{p}>0.05)$. 
varieties tested in this study showed a good level of resistance to early blight (Table 1). These results are in disagreement with those published by NEDER et al. (2010) and SIMON et al. (2009). These researchers noted significant differences in terms of resistance to early blight in an experiment conducted in the presence of pathogen inoculation. However, it should be emphasized that unlike these authors' study, there was no inoculation of $A$. solani in our study which may have influenced the expression of the disease in the field and the behavior and performance of the genotypes.

Potato genotypes and/or cultivars differed statistically in the incidence of late blight in the first crop cycle in Environment 1 (Table 2). In both environments, the severity of late blight did not differ between the genotypes and/or cultivars regardless of the crop cycle (Table 2). Genotypes 15, 35, 162, and 334 were the most resistant ones to late blight when the foliar incidence of the disease was assessed. The same ones were similar to genotypes cvs Ágata, BRS Ana, Catucha, Cota, and Monalisa in terms of resistance to this disease. Advanced clones 95 and
144 showed the highest incidence of late blight which was similar to genotypes cvs Asterix, BRS Eliza, and Panda and to clones 172 and 322.

In a study carried out by BARQUERO et al. (2005) in which genotype hybridization was performed, the progenies showed increased resistance to late blight (Phytophthora infestans) once resistance genes from the wild progenitor genotypes were introduced. However, in the present study; although, only two genotypes from hybridization assays showed high sensitivity to late blight, we were unable to determine if genotypes from hybridization studies are more resistant to late blight since 4 of the 8 clones tested belonged to the group of genotypes most susceptible to late blight $(50 \%)$ and 3 of the 7 cultivars tested were included in the group of the most susceptible ones $(43 \%)$. This is due to the fact that commercial varieties, even those traditionally preserved by farmers, present a certain degree of susceptibility to diseases since successive annual selections may favor production rather than resistance (ROBINSON, 2006). Thus,

Table 2 - Late blight intensity (Phytophthora infestans) expressed by the area below the incidence progression curve (AACPI) and severity (AACPS) in potato genotypes grown under organic system of cultivation in two cycles, years 2012/2013 and 2013/2014, Santa Catarina, Brazil.

\begin{tabular}{|c|c|c|c|c|c|c|}
\hline \multirow[t]{3}{*}{ Local genotypes Cultivars } & \multicolumn{4}{|c|}{ 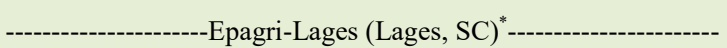 } & \multirow{2}{*}{\multicolumn{2}{|c|}{ Agricultor-Quilombo (Quilombo, SC) }} \\
\hline & \multicolumn{2}{|c|}{------------2012/2013----------- } & \multicolumn{2}{|c|}{-------------2013/2014----------- } & & \\
\hline & AACPI & AACPS & AACPI & AACPS & AACPI & AACPS \\
\hline 15 & $66.38 b$ & $11.60^{\mathrm{ns}}$ & $206.63^{\mathrm{ns}}$ & $8.40^{\mathrm{ns}}$ & $65.13^{\mathrm{ns}}$ & $28.26^{\mathrm{ns}}$ \\
\hline 35 & $61.88 \mathrm{~b}$ & 13.18 & 89.63 & 9.17 & 61.13 & 10.18 \\
\hline 95 & $134.25 \mathrm{a}$ & 14.40 & 93.25 & 10.56 & 56.34 & 10.65 \\
\hline 144 & $103.88 \mathrm{a}$ & 12.61 & 124.13 & 12.86 & 65.00 & 16.38 \\
\hline 162 & $46.50 \mathrm{~b}$ & 12.30 & 178.63 & 11.23 & 64.50 & 11.25 \\
\hline 172 & $90.76 a$ & 14.74 & 95.75 & 9.35 & 62.25 & 9.844 \\
\hline 322 & $98.38 \mathrm{a}$ & 14.33 & 173.63 & 82.03 & 57.38 & 10.13 \\
\hline 334 & $53.75 b$ & 37.72 & 128.25 & 12.04 & 43.39 & 9.825 \\
\hline ÁGATA & $60.88 b$ & 13.24 & 87.75 & 10.37 & 53.00 & 21.39 \\
\hline ASTERIX & $95.63 \mathrm{a}$ & 13.99 & 152.13 & 12.24 & 54.38 & 10.71 \\
\hline BRS ANA & $72.25 b$ & 13.11 & 105.88 & 9.52 & 54.88 & 10.93 \\
\hline BRS ELIZA & $91.13 a$ & 13.86 & 49.50 & 11.66 & 62.50 & 12.49 \\
\hline CATUCHA & $72.75 b$ & 12.64 & 91.50 & 11.23 & 59.5 & 9.769 \\
\hline COTA & $65.50 \mathrm{~b}$ & 12.30 & 80.88 & 12.96 & 55.75 & 9.563 \\
\hline MONALISA & $52.00 \mathrm{~b}$ & 11.96 & 130.00 & 14.25 & 60.63 & 10.71 \\
\hline PANDA & $83.13 \mathrm{a}$ & 27.34 & 118.25 & 70.02 & 48.31 & 11.06 \\
\hline $\mathrm{CV}(\%)$ & 14.26 & 6.96 & 17.23 & 11.75 & 11.35 & 8.64 \\
\hline
\end{tabular}

*Averages followed by the same letter in the column do not differ from one another by the Scott-Knott test ( $\mathrm{P} \leq 0.05)$. ns $=$ not significant by ANOVA F test $(\mathrm{P}>0.05)$. 
the resistance of genotypes to late blight may vary between genotypes, and may be stable or unstable. If resistance instability is detected in one particular genotype, it may be due to the environment, the population of the pathogen, or a combination of both factors (FORBES et al., 2005).

Note that clone 15 and cultivars BRS Ana and Cota exhibited the same behavior when affected by both early blight and late blight, i.e. they showed a lower incidence of AACPI and AACPS. Thus, these genotypes may be more appropriate to the crop when reduction in the intensity/decrease in the severity of both diseases in the organic system of cultivation is a trait pursued. In contrast, clone 95 was the genotype that presented one of the highest averages (means) of incidence for both pathosystems. Therefore, in conditions similar to the present research study, this genotype would not be the most recommended one if decreased incidence of these two diseases is a trait sought after through genetic control.

Results of tuber yield did not show any differences between genotypes in the two cycles of Environment 1 (Table 3). In Environment 2, genotype 35 and genotype cvsAsterix and BRS Ana presented the highest yields differing from the other genotypes tested. The second most productive class of genotypes included genotypes 15,95 , and 162 which did not differ from genotypes cvs Catucha, BRS Eliza, and Monalisa in terms of productivity (see Table 3 ).

Clone 15; although, in some cases did not differ from other genotypes, was one of the plants that presented a lower incidence rate (AACPI) of early blight and late blight. However, it remained in the intermediate group in terms of productivity. In contrast, genotype 95 which showed one of the highest incidence rates in both pathosystems, showed intermediate yield and higher number of tubers in the environments and cycles in which a statistical difference was observed. Thus, it is noted that genotype 95, despite having a lower incidence of diseases, did not affect the yield which suggested disease tolerance of this particular genotype. PINTO et al. (2010) described the importance of the study of local genotypes with regard to yield and genetic tolerance to diseases ensuring that local genotypes suffer less negative impacts in commercial cultivars even if infected by fungi. The authors also pointed out that this trait ensures productive stability in a wider range of environments.

The cultivar BRS Ana presented the highest yield average (Table 3) and was also one of the cultivars that showed a lower incidence of early blight and late blight. In contrast, the cultivar Cota, which had also presented a low incidence of both diseases, was included in the group of the least productive ones. However, this was the cultivar that presented a greater number of tubers in the environments and cycles in which there was statistical difference.

This finding shows that there is a correlation between the lower incidence of diseases of the cultivars and their productivity since a plant that is more resistant to a particular pathogen can develop better mechanisms of structural resistance (ROBINSON, 2006). Physical and/or biochemical barriers prevent a pathogen from invading the various tissues of plants and; therefore, block their colonization and halt loss of infected tissue and avoid a reduction of productive potential (BARQUERO et al., 2005).

The number of tubers per plant was higher in the genotypes 95 and cv Cota, considering two crop cycles, Environment 1, years 2013/2014, and Environment 2, years 2013/2014 in which a statistical difference was noted (Table 3 ). The lowest prolificacy which was evaluated by the number of tubers in 2 cycles occurred in BRS Ana and genotype 162 as well as the higher productivity observed in the BRS Ana cultivar did not result in a larger number of tubers (Table 3 ). Greater prolificacy of Cota cultivar and genotype 95 did not result in higher tubercle productivity. Thus, the average weight of tubers was not proportional to prolificacy under the conditions studied. SILVA et al. (2014) noted that potato varieties grown in the municipality of Pelotas, RS, south Brazil, showed larger tubers than in the environment of the south coast of Santa Catarina. This funding demonstrates that the productivity of the tubers may vary according to the conditions of each growing environment.

In the present study, genotype 35 was the only genotype that had high productivity $(1.6926,81 \mathrm{~kg}$ $\mathrm{ha}^{-1}$ ) being similar to that of cultivars Asterix and BRS Ana (Table 3). The results presented in our study do not corroborate the information previously published by other researchers that genotypes that are improved in the edaphoclimatic conditions of the planting site have a better productive performance than foreign and/ or improved genotypes. Generally, the cycle length of Creole genotypes is higher than that of the earliest commercial cultivars obtained by plant genetic improvement. Therefore, the longer vegetative cycle of Creole genotypes may directly interfere with the occurrence of diseases and yield of tubers (RODRIGUES et al., 2009). 
Table 3 - Production and average number of tubers per plant, in potato genotypes grown under organic system, in 2 cycles, years 2012/2013 and 2013/2014, Santa Catarina, Brazil.

\begin{tabular}{|c|c|c|c|c|c|c|}
\hline \multirow[t]{3}{*}{ Local genotypes/Cultivars } & \multicolumn{4}{|c|}{-------------------------Epagri-Lages Lages, SC-------------------------- } & \multirow{2}{*}{\multicolumn{2}{|c|}{ Agricultor-Quilombo Quilombo, SC }} \\
\hline & \multicolumn{2}{|c|}{-------------2012/2013-------------- } & \multicolumn{2}{|c|}{--------------2013/2014--------------- } & & \\
\hline & Yield $\left(\mathrm{kg} \mathrm{ha}^{-1}\right)$ & Tubers (plant ${ }^{-1}$ ) & Yield $\left(\mathrm{kg} \mathrm{ha}^{-1}\right)$ & Tubers $\left(\right.$ plant $\left.^{-1}\right)$ & Yield $\left(\mathrm{kg} \mathrm{ha}^{-1}\right)$ & Tubers $\left(\right.$ plant $\left.^{-1}\right)$ \\
\hline 15 & $2,0086^{\mathrm{ns}}$ & $9.03^{\mathrm{ns}}$ & $2,031.19^{\mathrm{ns}}$ & $7.03 \mathrm{~b}$ & $12,083.4 \mathrm{~b}$ & $5.88 \mathrm{a}$ \\
\hline 35 & $1,716.1$ & 7.30 & $1,679.92$ & $7.54 b$ & $16,926.1 \mathrm{a}$ & $4.97 \mathrm{a}$ \\
\hline 95 & $2,043.1$ & 9.92 & $1,662.94$ & $10.76 \mathrm{a}$ & $12,322.2 b$ & $5.97 \mathrm{a}$ \\
\hline 144 & $1,798.1$ & 7.08 & $1,845.80$ & $10.45 \mathrm{a}$ & $10,708.6 \mathrm{c}$ & $3.88 \mathrm{~b}$ \\
\hline 162 & $1,923.3$ & 8.04 & $2,111.55$ & $8.04 b$ & $13,228.6 b$ & $3.89 b$ \\
\hline 172 & $1,778.8$ & 7.52 & $2,008.75$ & $6.95 b$ & $9,051.94 \mathrm{c}$ & $6.06 \mathrm{a}$ \\
\hline 322 & $1,795.1$ & 10.04 & $1,250.24$ & $4.71 b$ & $4,906.17 \mathrm{c}$ & $5.09 \mathrm{a}$ \\
\hline 334 & $1,813.8$ & 7.66 & $1,768.98$ & $4.64 b$ & $7,572.80 \mathrm{c}$ & $6.13 \mathrm{a}$ \\
\hline ÁGATA & 990.34 & 6.93 & $1,704.95$ & $8.35 b$ & $10,041.1 \mathrm{c}$ & $5.95 \mathrm{a}$ \\
\hline ASTERIX & $2,152.9$ & 9.98 & $1,727.06$ & $6.83 \mathrm{~b}$ & $15,812.5 \mathrm{a}$ & $5.60 \mathrm{a}$ \\
\hline BRS ANA & $3,039.1$ & 10.35 & $2,379.90$ & $7.80 \mathrm{~b}$ & $18,208.4 \mathrm{a}$ & $2.65 b$ \\
\hline BRS ELIZA & $1,489.6$ & 8.37 & $1,709.35$ & $13.18 \mathrm{a}$ & $12,103.7 b$ & $4.08 \mathrm{~b}$ \\
\hline CATUCHA & $1,585.2$ & 8.42 & $2,339.62$ & $8.29 b$ & $11,499.2 b$ & $4.78 \mathrm{a}$ \\
\hline COTA & 988.27 & 4.81 & $1,113.23$ & $11.50 \mathrm{a}$ & $8,999.86 c$ & $5.53 \mathrm{a}$ \\
\hline MONALISA & $1,936.7$ & 6.48 & $1,661.43$ & $9.90 \mathrm{a}$ & $13,051.8 \mathrm{~b}$ & $4,24 b$ \\
\hline PANDA & $1,061.4$ & 7.38 & $1,449.83$ & $6.84 b$ & $8,895.69 \mathrm{c}$ & $4.94 \mathrm{a}$ \\
\hline CV (\%) & 14.44 & 9.33 & 10.41 & 15.81 & 27.51 & 24.2 \\
\hline
\end{tabular}

*Averages followed by the same letter in the column do not differ from one another by the Scott-Knott test $(\mathrm{P} \leq 0.05)$. ns $=$ not significant by ANOVA F test $(\mathrm{P}>0.05)$.

\section{CONCLUSION}

Local and commercial potato genotypes show variability in terms of productive potential and resistance to diseases under an organic cultivation system. Localgenotypes may have productive potential similar to that presented by commercial cultivars. Although, some clones and cultivars showed lower intensity of late blight and early blight, in general the genotypes tested in the present study did not show a good level of resistance to these diseases.

\section{ACKNOWLEDGEMENTS}

To Fundação de Amparo à Pesquisa e Inovação do Estado de Santa Catarina (FAPESC) through the Rede Guarani Serra Geral/TO 2015TR1067 that partially gave financial support to the project research. The second and the fith author are PQ 2 Conselho Nacional de Desenvolvimento Científico e Tecnológico (CNPq) scholarship researchers.

\section{DECLARATION OF CONFLICT OF} INTERESTS

The authors declare no conflict of interest. The founding sponsors had no role in the design of the study; in the collection, analyses, or interpretation of data; in the writing of the manuscript, and in the decision to publish the results.

\section{AUTHORS' CONTRIBUTIONS}

All authors contributed equally for the conception and writing of the manuscript. All authors critically revised the manuscript and approved of the final version.

\section{REFERENCES}

BARQUERO, M. et al. Resistance to late blight (Phytophthora infestans) in promising potato clones in Costa Rica. Agronomía Costarricense, v.29, n.3, p.31-45, 2005. Available from: $<\mathrm{http}: / /$ www.redalyc.org/html/436/43626961006>. Accessed: May, 7, 2018.

BERGER RD. The analysis of the effects of control measures on the development of epidemics. In: KRANZ J; ROTEM J .(Ed.). Experimental techniques in plant disease epidemiology, Heidelberg: Springer-Verlang, 1988, p.137-151.

BRUNE et al.New potato progenitors immune to PVY and PVX, and resistant to early blight. Horticultura Brasileira, v.17, n.2, p.173-174, 1999. Available from: <https://www.researchgate.net/ profile/Paulo_De_Melo2/publication/262466786_New_potato_ progenitors_immune_to_PVY_and_PVX_and_resistant_to_early_ blight/links/5697a15a08aea2d74375b09f/New-potato-progenitorsimmune-to-PVY-and-PVX-and-resistant-to-early-blight.pdf $>$. Accessed: Apr. 22, 2018. doi: 10.1590/S0102-05361999000200022. 
CARPUTO et al. Tuber quality and soft rot resistance of hybrids between Solanum tuberosum and the incongruent wild relative S. commersonii. American Journal of Potato Research, v.79, p.345-352, 2002. Available from: <https://link.springer.com/ article/10.1007/BF02870172>. Accessed: May, 25, 2018.

DUARTE et al. Field resistance of potato cultivars to foliar early blight and its relationship with foliage maturity and tuber skin types. Tropical Plant Pathology, v.39, n.4, p.294-306, 2014. Available from: <http://www.scielo.br/pdf/tpp/v39n4/v39n4a04. pdf>. Accessed: May, 25, 2018.

EMPRESA BRASILEIRA DE PESQUISAAGROPECUÁRIA. Sistema brasileiro de classificação de solos. Brasília: Embrapa. 2013, 353p. 3ed.

FNPPPT-FÉDERATION NATIONALE DES PRODUCTEURS DE PLANTS DE POMMES DE TERRE. Fiches Descriptives des Maladies et Ravageurs de la Pomme de Terre. Paris: MAME, 2000. 88p.

GOMES et al. Fertilization with silicon as resistance factor to pest insects and promoter of productivity in the potato crop in an organic system. Ciência Agrotécnica, v.33, n.1, p.18-23, 2008. Available from: $<$ http://prpg.ufla.br/_ppg/entomologia//wp-content/uploads/2012/08/7flavia-batista-gomes.pdf $>$. Accessed: Apr. 15, 2018.

GRUNWALD et al. Potato late blight management in the Toluca valley: Field validation of SimCast modified for cultivars with high field resistance. Plant Disease, v.86, n.10, p.1163-1168, 2002. Available from: $<$ https://pubag.nal.usda.gov/pubag/downloadPDF. $\mathrm{xhtml}$ ?id=11501\& content=PD $>$. Accessed: Apr. 15, 2018.

JAMES W.C. 1971. An illustrated series of assessment keys for plants diseases. Their preparation and usage. Cannadian Plant Disease Survey, v.51, n.2, p.39-65, 1971. Available from: $<$ https:// phytopath.ca/wpcontent/uploads/2014/10/cpdsarchive/vol51/ CPDS_Vol_51_No_2_(39-65)1971.pdf>.Accessed: Apr. 12, 2018.

LOURENÇO JR et al. Molecular diversityand evolutionary processes of Alternaria solani in Brazil inferred using genealogical and coalescent approaches. Phytopathology, v.99, n.06, p.765774, 2009. Available from: <https://apsjournals.apsnet.org/doi/ pdfplus/10.1094/PHYTO-99-6-0765>. Accessed: Apr. 12, 2018.

PASSOS et al. Yield of organic potato cultivars in the subtropical region of Brazil. Horticultura Brasileira, v.35, n.4, p.628-633, 2017. Available from: <http://www.scielo.br/pdf/hb/v35n4/18069991-hb-35-04-628.pdf>. Accessed: Apr. 12, 2018.

PINTO et al. Potential of elite potato clones as new cultivars for Minas Gerais State, Brazil. Horticultura Brasileira, v.28, n.4, p.399-405, 2010. Available from: $<$ http://www.abhorticultura.com. br/revista/revista_28_4/pe_2062.pdf $>$. Accessed: May, 13, 2018.
RIBEIRO G.H.M.R.; LEPRE A.L. Potencial de clones elite de batata como novas cultivares para Minas Gerais. Horticultura Brasileira, v.28, n.4, p.399-405, 2010. Available from: <http:// www.scielo.br/scielo.php?pid=S010205362010000400004\&scrip $\mathrm{t}=\mathrm{sci}$ abstract\&tlng $=\mathrm{pt}>$. Accessed: Apr. 11, 2018. doi: 10.1590/ S0102-05362010000400004.

ROBINSON R.A. Return to resistance: breeding crops to reduce pesticide dependence, Canada: Sharebook pub. 2006, 569p., 3ed.

RODRIGUES et al. Selection for vegetative growth period and its relationship to tuber yield of potato. Horticultura Brasileira, v.27, n.3, p.280-285, 2009. Available from: <https://s3.amazonaws.com/ academia.edu.documents/46485185/Seleo_para_durao_do_ciclo_ vegetativo_em_20160614-39621dxw0iw.pdf?AWSAccessKeyId $=$ AKIAIWOWYYGZ2Y53UL3A\&Expires $=1528670277 \&$ Sign

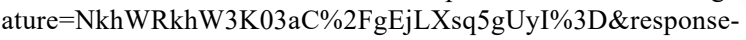
content-disposition $=$ inline $\% 3 \mathrm{~B} \% 20$ filename $\% 3 \mathrm{DSelecao}$ para_ duracao_do_ciclo_vegetativo.pdf>.Accessed: Mar. 21, 2018.

RODRIGUES et al. First report of Alternaria tomatophila and A. grandis causing early blight on tomato and potato in Brazil. New Disease Reports, v.22, n. p.28-28, 2010. Available from: $<$ https://www. ndrs.org.uk/pdfs/022/NDR_022028.pdf>. Accessed: Mar. 21, 2018.

ROSSI F. et al. Potato cultivars for organic production systems, Horticultura Brasileira, v.29, n.3, p.372-376, 2011. Available from: <http://www.producao.usp.br/bitstream/handle/ BDPI/11390/art_ROSSI_Cultivares_de_batata_para_sistemas_ organicos_de_2011.pdf?sequence=1>. Accessed: Mar. 21, 2018.

SIMON et al. Potato clones selection for early blight resistance and heat tolerance, Revista Ceres, v.56, n.1, p.31-37,2009. Available from: $<$ http://www.redalyc.org/html/3052/305226702004>. Accessed: Apr. 02, 2018.

SILVA et al. Selection of potato clones based on selection indexes. Revista Ceres, v.61, n.6, p.941-947, 2014. Available from: <http:// www.redalyc.org/html/3052/305232929008/>. Accessed: Apr. 02, 2018. doi: 10.1590/0034-737X201461060008.

STEVENSON et al. Compendium of Potato Diseases, APS Press, 2013.144p. 2 ed.

ZAMBOLIM L.; DUARTE H.S.S. Controle integrado das doenças da batata, (Informe Agropecuário), v.33, n.270, p.64-80, 2012.

RAUBER et al. Pest management potatoes by homeopathic preparations and genotype variability. Revista Brasileira de Agroecologia, v.2, n.2, 2007. Available from: <http://revistas.abaagroecologia.org.br/index.php/rbagroecologia/article/view/6997>. Accessed: Apr. 10, 2018. 